\title{
СТАНОВЛЕНИЕ НОРМАТИВНЫХ И ИНСТИТУЦИОНАЛЬНЫХ ОСНОВ УГОЛОВНОЙ ОТВЕТСТВЕННОСТИ ЗА ВОЕННЫЕ ПРЕСТУПЛЕНИЯ: К ВОПРОСУ О ПЕРИОДИЗАЦИИ
}

Аннотация. В статье рассматривается эволючия развития норм об уголовной ответственности за военные преступления и её институциионально-правового механизма. Проведена периодизация данного прочесса, с учетом принципиальных изменений юридической техники криминализации военных преступлений, порядка конкретизации и реализации уголовной ответственности за их совершение. Показана корреляция становления норм и механизма уголовной ответственности за военные преступления с эволюичией развития национальных и международной правовых систем, а также с усилением взаимосвязи между ними в современных условиях. Начало современного периода рассматриваемого эволючионного процесса связано с работой и приговором Нюрнбергского МВТ, а с 1990-х годов наблюдаются новые тендениии, связанные с диверсификаиией органов международной уголовной юстиичи, созданием постоянного международного уголовного суда, развитием процесса национально-правовой имплементации международных обязательств, формированием системы взаимодействия национальных и международных правоприменительных органов в сфере уголовной ответственности за военные преступления.

Ключевые слова: Военные преступления, уголовная ответственность, периодизация, военно-уголовное право, международное право, начиональное право, международная уголовная юстиция, националная уголовная юстиция, уголовное судопроизводство, военный суд.

Abstract: This article examines the evolution of development of the norms on criminal responsibility for the war crimes and its constitutional-legal mechanism. The author presents periodization of this process, taking into account the essential changes of the juridical technique of criminalization of the war crimes, as well as the order of concretization and realization of the criminal responsibility for committing them. The work demonstrates the correlation between the establishment of the norms and mechanism of criminal responsibility for the war crimes with the evolution of development of the national and international legal systems, as well as with the strengthening of interrelation between them under the current circumstances. The beginning of the contemporary period of the reviewed evolutional process is linked to the work and decision of the Nuremberg trials, and in the 1990's we can observe the new trends associated with diversification of the branches of the international criminal justice, development of the process of the national-legal implementation of international obligations, and the establishment of the system of collaboration of the national and international law enforcement agencies in the area of criminal responsibility for the war crimes.

Keywords: National criminal justice, international criminal justice, national law, international law, military criminal law, periodization, criminal responsibility, war crimes, criminal proceedings, military court. 
K ак известно, история человечества отражена в войнах, общей характерной чертой которых являются многочисленные и грубые нарушения правил их ведения и неоправданное военной необходимостью насилие. Как следствие, постепенно складывается практика ограничения воюющих в выборе средств и методов ведения войны, в том числе, при помощи мер уголовной репрессии. Изучение процесса эволюции реагирования отдельных государств и международного сообщества в целом на факты серьезных нарушений законов и обычаев войны позволяет выявить определенные закономерности в создании норм и органов такого рода реагирования, проследить современные тенденции его развития, с учетом преемственности в праве.

Вопросы становления и развития нормативных и институциональных основ уголовной ответственности за военные преступления рассматриваются в специальной литературе применительно к отдельным аспектам ее формирования и реализации, либо в контексте более общих проблем, некоторыми авторами также предлагаются (с учетом исследуемых аспектов) варианты периодизации. Так, И.Ю. Белый в результате историко-правового анализа становления и развития институтов международного сотрудничества в сфере уголовного судопроизводства, приходит к выводу, согласно которому к основным этапам становления и развития международного уголовного судопроизводства по делам о военных преступлениях относятся: зарождение и разработка доктрины международного уголовного преследования за военные преступления (первый период, с 1815 г. по 1945 г.); формирование правовых основ международного уголовного судопроизводства по делам о военных преступлениях (второй период, с 1945 г. по 1993 г.); создание системы органов международного уголовного правосудия (третий период, с 1993 г. по настоящее время) $[12,20]$.

Не оспаривая обоснованность суждений указанного автора применительно к теме международного уголовного судопроизводства, мы, вместе с тем полагаем, что процесс становления отдельных норм об уголовной ответственности за военные преступления, а также практики привлечения к ней и ее реализации начинается намного раньше. Представляется, что в основу периодизации рассматриваемой разновидности уголовной ответственности должны быть положены принципиальные изменения в юридической технике нормативно-правового отражения ее оснований и форм, а также в механизме ее конкретизации и реализации. Данные изменения, в свою очередь, во многом производны от изменений национальных и международной правовых систем в процессе их эволюционного развития и усиления взаимосвязи между ними, кроме того, они отражают изменения военной организации государств, становление и развитие военно-уголовного права.

Анализ специальной литературы [11, $318-327 ; 20,3 ; 58,11-26]$ и соответствующих правовых памятников позволяет высказать мысль о том, что уже в древние, античные и средневековые времена предпринимались попытки ограничить воюющих в выборе средств и методов вооружённой борьбы, и были прецеденты осуждения виновных в наиболее серьёзных нарушениях такого рода. При этом заслуживают внимания следующие обстоятельства. Во-первых, длительный период времени (вплоть до XVI в.) в правовом регулировании ведения войн и установлении соответствующих запретов и ограничений преобладал обычай.

Во-вторых, установление ограничений и запретов, налагаемых на воюющих, в большинстве случаев не было связано с гуманными соображениями, а преследовало 
достижение тактических или экономических целей, либо было направлено на укрепление воинской дисциплины. В целом же, долгое время война носила тотальный характер, фактически велась не только с вооруженными силами государства, но и со всем населением страны, захваченные города и поселения подвергались разграблению и уничтожению, их жители истреблялись и уводились в рабство.

В-третьих, в формировании запретов и ограничений ведения войн важную роль (особенно в средние века) играла религия. Именно под влиянием церкви сложились обычаи уважения неприкосновенности религиозных учреждений (храмов, монастырей, школ и т.п.), а также лиц, принадлежащих к духовному сословию, вводились ограничения на применение оружия, создавались различные организации, которые предоставляли защиту священнослужителям, женщинам, детям и старикам и запрещали ведение военных действий в периоды религиозных праздников, был сформирован свод правил (кодекс рыцарской чести), согласно которым недопустимы были вероломство, а также насилие в отношении женщин и сирот.

Принято считать, что первый международный процесс над военным преступником (здесь мы абстрагируемся от того, что сам термин «военные преступления» бы введен в научный оборот и получил нормативно-правовое отражение только в начале XX в., в связи с событиями Первой мировой войны) состоялся над Петером фон Хагенбахом в 1474 году [17, 32-42].

Таким образом, в древний, античный и средневековый периоды происходит зарождение запретов и ограничений, касающихся ведения войны, и начинает формироваться практика уголовной ответственности за их серьезные нарушения.

Начало следующего этапа становления норм и механизма уголовной ответствен- ности за военные преступления связано с разработкой и принятием правовых актов национального законодательства отдельных государств, специально посвященных вопросам военного строительства, и устанавливающих, в том числе, ответственность воинских формирований и входящих в них лиц за нарушение законов и обычаев войны [21, 190]. Данный процесс (назовём его внутригосударственной практикой криминализации отдельных нарушений законов и обычаев ведения войны в военно-уголовном законодательстве) начинается в XVI веке. Заметим, что в России уголовная ответственность за военные преступления («посягательство на существовавшие в войсках отношения к личности (населению) и имуществу жителей театра войны») впервые устанавливается в эпоху Ивана IV (Грозного), который по свидетельству историков, строго наказывал за насилие войск против мирного населения, если на то не было особого дозволения $[57,14]$.

В дальнейшем наблюдается совершенствование военно-уголовного законодательства, кроме того, разрабатываются правила военно-уголовного судопроизводства, появляются органы военной юстиции, к ведению которых были отнесены вопросы уголовной ответственности военнослужащих, в том числе, за совершение преступлений в отношении мирного населения и его имущества. По мнению исследователей $[20,14]$, первым нормативно-правовым актом, в котором в систематизированном виде содержались положения об уголовной ответственности военнослужащих за причинение вреда гражданскому населению было, принятое в 1702 г. Уложение фельдмаршала Б. Шереметьева.

В формировании российского военноуголовного права, как и в целом российской военной организации, особую роль сыграли преобразования Петра I, начавшего созда- 
вать новую регулярную армию по западноевропейскому образцу (в основу новой военной организации были положены всеобщая воинская обязанность, обучение и воспитание войск, централизованное руководство и единоначалие, жесточайшая воинская дисциплина). Правовые акты, разработанные и изданные в эпоху Петра I (преимущественно, уставы, артикулы), как признают исследователи $[15,136-138 ; 72,10-14 ; 81]$, отличались достаточно высокой юридической техникой: в них были использованы наиболее емкие и абстрактные формулировки, наблюдается отход от традиционной для права того времени казуальной системы. В контексте исследуемой темы, выделим Воинский устав (1716 г.) (Образиом для Воинского устава послужили шведские военные артикуль Густава Адольфа (1621) в редакиии Карла V (1683).), часть вторая которого (Артикул воинский) заключал в себе, главным образом, нормы военно-уголовного права и предусматривал, в частности, уголовную ответственность за ряд преступлений против мирного населения [57, 46].

Третья часть Устава воинского («Краткое изображение процессов или судебных тяжб») подробно регулировала вопросы судоустройства и судопроизводства, в том числе при рассмотрении уголовных дел о рассматриваемой категории преступлений (По мнению О.И. Чистякова, краткое изображение процессов или судебных тяжб представляет собой военно-процессуальный кодекс. - См.: Законодательство Петра I. - M., 1997. C. 800). Интересно отметить, что данная система военно-уголовного судопроизводства в целом просуществовала до Военно-судебной реформы 1867 года [9].

Правомерно высказать мысль о том, что именно в период государственно-правовых и военных преобразований Петра I были созданы органы военной юстиции, к компетенции которых относились дела о преступлениях, совершенных военнослужащими, включая рассматриваемые преступные нарушения.

Военно-уголовный устав (1839) [76] так же как и Артикул воинский (1716) предусматривал три группы преступлений военного времени, одна из которых объединяла преступления против законов и обычаев войны, причем их перечень был расширен и включал: а) насильственные действия в отношении гражданского населения в военное время (ст. 625, 626); б)имущественные преступления в отношении гражданского населения (ст. 621, 622, 632, 633); в) убийство военнопленного (ст. 605); г) насильственные действия в отношении военнопленного (ст. 609). Как видим, в Военно-уголовном уставе юридическая техника описания составов рассматриваемых нарушений практически достигла принятых в современном уголовном праве стандартов, их перечень стал включать в себя, наряду с посягательством на личные и имущественные интересы гражданского населения, также посягательство на безопасность военнопленных.

Следует обратить внимание на то, что процесс становления и развития военно-уголовного законодательства государств вплоть до середины XIX в. не испытывал влияния со стороны международного права и международной правовой системы, что, по всей видимости, объясняется недостаточным развитием последних в тот период времени. Международно-правовая составляющая в исследуемой сфере в это время ограничивается отдельными вопросами (в частности, экстрадицией).

Проблема привлечения к уголовной ответственности за деяния, причинившие ущерб интересам содружества государств была поднята при обсуждении в 1815 г. антифранцузской коалицией намерения о предании суду Наполеона Бонапарта по обвинению в гибели сотен тысяч людей и иных 
преступлениях во время многочисленных наполеоновских войн (Ж. Пикте приводит такой пример: во время Египетской кампании, когда Наполеон был еще генералом, он хладнокровно велел убить штыками и ружьями 4000 турецких солдат гарнизона города Яффы, сдавшихся на условиях сохранения им жизни. - См. Пикте Ж. Указ. соч. C. 34.). Однако за состоявшимся обсуждением действий не последовало [23].

Таким образом, второй выделяемый нами период (XVI в. - середина XIX в.) характеризуется становлением военно-уголовного законодательства государств, криминализацией в нем отдельных нарушений законов и обычаев войны, формированием специальных правил и органов военно-уголовного судопроизводства, распространяющего свое действие на дела об указанных нарушениях. Заметим, что по мере совершенствования военной организации государств (переходу к регулярной и дисциплинированной армии), развития военного и военно-уголовного права изменяется общий подход к ведению военных действий, более четкими и развернутыми становятся законодательно установленные запреты и ограничения для воюющих. Постепенно гражданское население в целом (а не его отдельные категории, как это было ранее) перестает рассматриваться в качестве военного противника, насильственные действия в отношении гражданского населения, военнопленных влекут уголовную ответственность, причем наступление последней перестает зависеть от усмотрения правителя или военачальника.

Роль международно-правовой составляющей в исследуемой сфере возрастает, начиная со второй половины XIX века. В это время начинают реализовываться проникнутые идеей гуманизации вооруженных конфликтов инициативы частных лиц и государственных деятелей, связанные с объединением усилий международной общественности и государств в создании правовых основ и механизмов защиты раненых, военнопленных, гражданского населения, ограничении воющих в выборе средств и методов ведения военных действий. Так, во многом благодаря подвижнической деятельности швейцарских граждан Анри Дюнана и Гюстава Муанье в 1863 г. был создан Международный комитет помощи раненым (с 1880 г. и по настоящее время - Международный Комитет Красного Креста) [58, 35-37]. В 1864 г. швейцарское правительство созвало дипломатическую конференцию для выработки документа о помощи жертвам войны. Участники конференции (12 государств) подписали первую многостороннюю Конвенцию о защите раненых и больных во время войны (1864), в которой была реализована идея А. Дюнана, и к которой впоследствии присоединились более 50 государств, в том числе Россия (Примечательно, что в России еще до создания Международного Комитета Красного Креста была создана Крестовоздвиженская община сестер милосердия, которой руководил русский хирург Н.И. Пирогов, и которая оказывала помощь раненым и больным на поле боя во время Крымской войны (1853-1856).).

В 1863 г. в США американский юрист Ф. Либер подготовил Инструкцию полевым войскам. Изданная президентом США А. Линкольном во время гражданской войны как общий приказ № 100, Инструкция (называемая также «Кодекс Либера»), во-первых, подтверждала все более широкое признание принципа, согласно которому следует щадить личность, имущество и честь безоружных граждан в той мере, в какой это согласуется с требованиями войны (ст. 22), во-вторых, устанавливала положение о том, что излишнее насилие, совершенное против лиц в стране, подвергшейся вторжению, любое уничтожение имущества иначе как по приказу уполно- 
моченного офицера, любой разбой, грабеж или присвоение, даже после занятия места основными силами, любое изнасилование, ранение, причинение увечий или убийство таких жителей запрещаются под страхом смертной казни или другого сурового наказания, которое может считаться адекватным с учетом тяжести правонарушения (ст. 44), в-третьих, устанавливала, что если кто-либо намеренно причиняет дополнительные ранения противнику, полностью утратившему боеспособность, или убивает такого противника, или приказывает или подстрекает солдат к таким действиям, подлежит казни по надлежащему приговору, принадлежит ли он к армии Соединенных Штатов Америки или является противником, захваченным после совершения таких действий (ст. 71) (Положения указанного документа приведены из материалов Постановления Большой Палаты ЕСПЧ от 17.05.2010. Дело «Кононов (Kononov) против Латвии» (жалоба N 36376/04) [Электронный ресурс] // Бюллетень Европейского Суда по правам человека», 2010, $N$ 8. Доступ из справ. правовой системы «Консультант Плюс». $O$ «Кодексе Либера, см., также: Schindler, Toman (eds.). The Laws of Armed Conflicts. Martinus Nijhoff Publishers, Dordrecht / Henry Dunant Institute. Geneva, 1988.). В отечественной и зарубежной литературе $[73,5 ; 37,13]$ высказано мнение о том, что «Кодекс Либера» был взят за основу при первой попытке кодификации обычаев войны в ходе Брюссельской конференции 1874 г. и последующей разработки Гаагских конвенций 1899 и 1907 гг.

Вместе с тем, следует отметить весомый вклад России в формирование и прогрессивное развитие международного гуманитарного права (международного права в период вооруженных конфликтов), в том числе в рассматриваемый период времени.
Как обоснованно полагает И.И. Котляров $[46,145]$, ретроспективный анализ истории появления и становления международного гуманитарного права свидетельствует о том, что именно Россия проявляла инициативу в разработке международных нормативных правовых актов, направленных на гуманизацию вооруженных конфликтов и принимала самое активное участие в их имплементации в национальное право, неукоснительно соблюдая их в период войн XIX века (На данные обстоятельства обращуают внимание и другие исследователи. - См., например: Шайкин В.И. Законы и обычаи войны в русской военной истории [Электронный ресурс] // Военно-юридический журнал. 2010. N 2. C. 28 - 32. Доступ из справ. - правовой системы «Консультант Плюс».). Так, именно по инициативе России в рассматриваемый период:

- была созвана конференция, завершившаяся принятием 29 ноября (11 декабря) 1868 г. Санкт-Петербургской декларации, в которой были провозглашены основополагающие принципы права ведения военных действий и содержался запрет на использование взрывчатых снарядов весом менее 400 граммов (Текст Декларации опубликован: Действующее международное право. Т. 2. - М.: Московский независимый институт международного права, 1997. C. 573 - 574.);

- был внесен на рассмотрение Брюссельской международной конференции (1874) проект Конвенции о законах и обычаях войны;

- были проведены первая и вторая Гаагские конференции мира 1899 и 1907 гг. [18, 2-7; 61], где, соответственно, был принят ряд принципиально важных для формирования международных законов и обычаев войны документов, в том числе Конвенция о законах и обычаях сухопутной войны (Ha созванной по инициативе России первой 
Гаагской конференции мира (1899) были подписаны три конвенции: «О мирном разрешении международных споров»; «О законах и обычаях сухопутной войны»; “О применении кморской войне начал Женевской конвенции 1864 г.; кроме того, приняты Декларации: «О запрещении сроком на пять лет метания снарядов и взрывчатых веществ с воздушных шаров», "О неупотреблении снарядов, имеющих единственным назначением распространять удушливые и вредоносные газыl»; "О неупотреблении легкоразворачивающихся или сплющивающихся пуль». На второй Гаагской конферениии мира (1907) были пересмотрены три ранее принятые конвенции и сформулированы десять новых, среди них Гаагские конвеничи (1907): I Гаагская конвенция «О мирном разрешении международных споров»; III Гаагская конвенция «Об открытии военных действий»; IV Гаагская конвенция «О законах и обычаях сухопутной войныр с входящим в ее состав приложением «Положение о законах и обычаях сухопутной войныл».).

Как видим, правила, применяемые при вооруженных конфликтах и нацеленные на предупреждение и пресечение насилия, не оправданного военной необходимостью, подвергаются не только внутригосударственной, но и международно-правовой кодификации (В теории права обоснованно отмечается прогрессивная роль кодификации как особого вида правотворческой деятельности, который обеспечивает единое, согласованное и упорядоченное нормативное регулирование конкретного вида сочиальных отношений, тем самым способствуя системному развитию всего нормативного материала. - См., например: Алексеев С.С. Теория права. М., 1993. С. 84.) на рубеже XIX - XX вв., причем международно-правовая систематизация законов и обычаев войны во многом опиралась на опыт отдельных национальных правовых систем.
В подготовке и проведении первой и второй Гаагских конференций мира особенно заметна роль известного российского дипломата и ученого Ф.Ф. Мартенса [48, $3-8 ; 62,105-114]$. Именно по его настоянию в преамбулу Конвенции о законах и обычаях войны (1899) было включено положение о том, что в случаях, не предусмотренных Конвенцией, «население и воюющие стороны остаются под охраной и действием норм международного права, поскольку они вытекают из установившихся между образованными народами обычаев, из законов человечности и требований общественного сознания». Это положение, известное как «декларация Мартенса» или «оговорка Мартенса», во многом определило дальнейший ход кодификации международного гуманитарного права (международного права в период вооруженных конфликтов) (Оговорка Ф.Ф. Мартенса вошла также в преамбулу Гаагской конвенции о законах и обычаях сухопутной войны и $\mathrm{cm}$. 1 (n. 2) I Дополнительного протокола к Женевским конвенциям о защите жертв войны (1949).), и, с учетом направленности на восполнение неизбежных пробелов в данной отрасли, очевидно, имеет непреходящее значение.

Россия учитывала нормы международных соглашений, направленных на ограничение средств и методов ведения войны и обеспечение гуманного отношения к лицам, не принимающим участия в боевых действиях, в процессе совершенствования военного и военно-уголовного законодательства; подтверждением могут служить Наказ русской армии о законах и обычаях сухопутной войны (1904), «Положение о военнопленных» (1914).

Воинский устав о наказаниях (1869) (B 1875 2. Воинский устав о наказаниях был переиздан и действовал вплоть до 1917 г., будучи издан в редакииях 1900 г. и 1913 г. Последнее издание Воинского устава о 
наказаниях было осуществлено в 1916 г., куда были внесены изменения, произошедшие с 1913 по 1916 г. - См.: Юшин В.Ю. Историко-юридическая характеристика военно-уголовного законодательства России [Электронный ресурс] //Военноюридический журнал. 2008. №4. Доступ из справ. - правовой системы «Консультант Плюс».) к совершаемым в условиях военного времени преступлениям против законов и обычаев войны (нас, принимая во внимание тему исследования, интересует эта группа воинских преступлений), относил: а) насильственные действия в военное время в отношении гражданского населения (ст. 279); б) имущественные преступления в отношении гражданского населения (ст. 279); в) дурное обращение с военнопленными (ст. 258); неправомерное использование знаков Красного Креста (ст. 258.1) [66, 180-181].

Механизм реализации положений Воинского устава был заложен Военно-судебным уставом (1867) [59].

Параллельно с процессом становления кодификации международного гуманитарного права (права вооруженных конфликтов) и совершенствованием (в том числе, под влиянием этого процесса) национального военно-уголовного законодательства, в рассматриваемый период продолжается разработка международных и внутригосударственных нормативно-правовых актов по вопросам правовой помощи и экстрадиции $[22,73-76 ; 53,515-516]$.

Попытка криминализовать военные преступления в международном праве и создать основанный на международном праве механизм реализации уголовной ответственности за их совершение была предпринята швейцарским юристом Муанье: в 1872 г. он предложил учредить Международный трибунал для предупреждения и преследования виновных в нарушении Женевской конвенции 1864 г [43, 238-240]. В соответствии со статьями проекта воюющие стороны могли обращаться в Международный трибунал с жалобой на нарушителей Конвенции. Трибунал должен был состоять из пяти членов: два - от воюющих сторон, три - от нейтральных стран по жребию. Если нейтральное государство, имеющее в трибунале представителя, вступило в войну, то назначенный им арбитр выбывал из состава трибунала и по жребию заменялся представителем другого нейтрального государства - ст. 2 проекта. Трибунал был правомочен рассматривать дела только по жалобам воюющих сторон; установив виновных, трибунал определял наказание в соответствии с дополнительным к Женевской конвенции соглашением - ст. 4; кроме осуждения к наказанию трибунал мог осудить к возмещению пострадавшему причиненного ущерба.

Термин «преступники войны» (war criminals) вошел в обиход только после Первой мировой войны; к этому же времени относится первая попытка применения международной уголовной юрисдикции по делам о преступных нарушениях права войны. В понятие «преступники войны» вкладывались два значения: в более широком смысле под ними понимались как виновники военной агрессии, так и лица, ответственные за нарушение законов и обычаев войны, в более узком смысле - только нарушители законов и обычаев войны. К этому же времени относится первая попытка классификации военных преступлений: Комиссия пятнадцати, созданная на Парижской мирной конференции, в своем докладе от 29 марта 1919 г. представила список тридцати двух составов международных преступлений, совершенных германскими военнослужащими и объединенных в две группы. Первая группа была представлена противоправными деяниями, квалифицируемыми в качестве военных преступлений, совершенных в нарушение 
общепризнанных правил ведения военных действий. К ним были отнесены применение отравляющих газов и разрывных пуль; потопление госпитальных и других невоенных судов; убийства военнопленных; совершение жестокостей по отношению к захваченным раненым и больным; разграбление частной собственности. Вторую группу составляли отдельные преступления, совершенные в ходе войны германскими властями в отношении собственных граждан (незаконное применение репрессий и судебных преследований, причинение телесных повреждений, нанесение ущерба здоровью или достоинству человеческой личности). Однако затем Комиссия отказалась от такой классификации и провела ее с учетом субъектов преступлений, которые подлежали судебному преследованию и уголовному наказанию в специальном экстерриториальном порядке [3, 35-36]. Версальский договор в части VII, озаглавленной «Санкции» (ст. 227-229), предусмотрел три вида юрисдикции по делам о преступлениях, связанных с войной: 1) специальный международный трибунал из представителей пяти союзных держав (США, Великобритании, Франции, Италии, Японии) для суда над бывшим германским императором Вильгельмом II; 2) военные суды государств, в юрисдикцию которых входило рассмотрение дел о совершении преступных нарушений законов и обычаев войны, направленных против их граждан; 3) смешанные суды, состоящие из представителей нескольких заинтересованных государств по делам о военных преступлениях, затрагивающих одновременно их интересы. Кроме того, в разделе III части IV Версальского договора устанавливалось обязательство его сторон преследовать в уголовном порядке и выдавать предполагаемых военных преступников (Cм.: Коровин Е.А. Международные договоры и акты нового времени. Сборник. - М. - Л.:
Госиздат, 1924. С. 47-97; Полянский Н.Н. Международное правосудие и преступники войны. М., 1945. С. 35 - 37.

Интересно, что идея создания смешанных международных уголовных судов была апробирована в Великобритании в XIX в.: на основе двусторонних договоров с рядом государств были учреждены смешанные международные трибуналы, компетентные принимать решения об уничтожении и конфискации морских судов, используемых в иелях работорговли, а также решения о выдаче преступников государствам, в подданстве которых они состоят. Меры наказания за совершенные международные преступления, согласно упомянутым договорам, определялись национальным законодательством государств-участников. - См.: Трикоз Е.Н. Преступления против мира и безопасности человечества: сравнительный и международно-правовой аспекты. С. 5-6.).

Данный механизм, по известным причинам, оказался практически невостребованным (Суд над Вильгельмом II не состоялся, поскольку Нидерланды отказали в его выдаче. Из 896 высших германских руководителей, обвиняемых союзниками в совершении военных преступлений (в нарушении законов и обычаев войныл)), только единицьь реально понесли уголовное наказание и то на основании Военного уголовного кодекса Германии и ее Императорского уголовного кодекса из-за отсутствия международных уголовных норм и международного судебного органа. - Об этом, см.: Аричибасов И.Н., Егоров С.А. Вооруженный конфликт: право, политика, дипломатия. М., 1989. С. 185; Международное право: Учебник / Отв. ред. В.И. Кузнеиов. - М.: Юрист, 2001. С. 657; Волеводз А.Г. Правовое регулирование новых направлений международного сотрудничества в сфере уголовного проиесса. - М.: Юрлитинформ, 2002. С. 77. ). Однако нельзя отрицать определенное по- 
зитивное значение Версальского договора и состоявшихся судебных процессов над отдельными германскими военнослужащими. Во-первых, впервые была предпринята попытка международно-правовой кодификации норм об уголовной ответственности за военные преступления и запуска основанного на международном договоре диверсифицированного (включающего межгосударственный и внутригосударственный уровни) юрисдикционного механизма ее реализации. Во-вторых, заложенная в Версальском договоре идея уголовной ответственности физических лиц за нарушение норм права войны получила (хотя и в сильно усеченном, видоизмененном виде) апробацию.

Заметим, что на национально-правовом уровне также предпринимались попытки создания специального механизма расследования нарушений законов и обычаев войны. Так, в 1915 г. по инициативе Правительства Российской империи и почину Государственной Думы была создана Чрезвычайная следственная комиссия для расследования фактов нарушений, допущенных австро-венгерскими и германскими войсками в отношении российских подданных, возвращавшихся в Россию из Германии и Австро-Венгрии, а также мирных жителей г. Калиша (Положение о данной Комиссии было высочайше утверждено 9 апреля 1915 г., о результатах расследования ею был подготовлен Обзор деятельности, который был издан в 1916 г. в Петрограде. - См.: Маликов C.В. Расследование преступлений в боевой обстановке (правовое обеспечение, организация, методика): Дис...канд. юрид. наук. - M., 1998. C. 37-38).

Отечественное военно-уголовное законодательство 1920-х годов включало нормы об уголовной ответственности за нарушение законов и обычаев войны [56, 22-26].
Таким образом, третий выделенный нами период (вторая половина XIX в. начало Второй мировой войны) характеризуется привнесением в рассматриваемый эволюционный процесс международно-правовой составляющей: на базе становления международно-правовой кодификации законов и обычаев войны, правил гуманного обращения с жертвами войны и формирования нормативно-правовых основ международного сотрудничества в борьбе с преступностью предпринимаются попытки криминализации военных преступлений в международном праве и запуска основанного на международном договоре диверсифицированного (включающего межгосударственный и внутригосударственный уровни) институционально-правового механизма уголовной ответственности за них (Мы вполне разделяем мнение Р.А. Елисеева о том, что становление отрасли международного уголовного права было обусловлено формированием межгосударственного экстрадиционного права и выделением особой подотрасли международного военно-уголовного права. - См.: Елисеев Р.А. Международное уголовное право: особенности правореализачии. Автореф. дис...к.ю.н. С. 10.). Положения международных соглашений в сфере международного гуманитарного права (права вооруженных конфликтов), а также по вопросам экстрадиции начинают учитываться государствами при разработке законодательства, регулирующего отношения в исследуемой сфере.

Новой вехой становления международной уголовной ответственности за военные преступления и кодификации норм об ответственности за их совершение стали судебные процессы, проходившие во время и, особенно после окончания Второй мировой войны. Среди них выделяется Нюрнбергский процесс над главными не- 
мецкими военными преступниками, имеющий важное, без преувеличения непреходящее значение, как для развития международного права, так и для международной системы в целом. Осудив главных немецких военных преступников, и, одновременно, признав преступными основные нацистские структуры (гестапо, СС, НСДАП), Нюрнбергский международный военный трибунал, по сути, юридически оформил запрет фашистской идеологии. Не случайно, принципы международного права, признанные Уставом Нюрнбергского Трибунала и нашедшие отражение в его приговоре, были подтверждены Генеральной Ассамблеей OOH [64, 550], а ход, итоги и уроки Нюрнбергского процесса продолжают осмысливаться исследователями [10, 24-30; 13, 14-18; 16; 32, 50-54].

В учредительных документах Нюрнбергского МВТ были четко определены материально-правовые основания уголовной ответственности за военные преступления; Нюрнбергский МВТ отверг своими решениями господствовавшую до этого доктрину государственного акта и дал правовое обоснование институту индивидуальной уголовной ответственности за преступления против мира, военные преступления и преступления против человечности, реализовал идею неотвратимости наказания военных преступников, невзирая на их официальный статус, ссылки на выполнение приказа, отсутствие во внутригосударственном праве установлений о преступности и наказуемости деяний, грубо нарушающих охраняемые международным правом интересы мира и безопасности человечества.

В целом же в Нюрнберге был впервые запущен международно-правовой механизм уголовной юрисдикции в связи с совершением международных (в том числе, военных) преступлений, и в этом плане создание и деятельность Нюрнбергского МВТ имели существенное значение для последующего развития органов международной уголовной юстиции.

19 января 1946 г. был учрежден Международный военный трибунал для Дальнего Востока (Токийский МВТ) в целях справедливого и быстрого суда и наказания главных военных преступников на Дальнем Востоке и утвержден его Устав. В п. «б»ст. 5 Устава Токийского МВТ определено, что трибуналу подсудны «военные преступления, предусмотренные конвенциями, а именно: преступления против законов и обычаев войны». Положения Токийского МВТ во многом заимствованы из Устава Нюрнбергского MBT $[67,86]$.

Важно отметить, что создание Нюрнбергского и Токийского МВТ не умаляло компетенции и не ограничивало прав национальных или оккупационных судебных органов, которые были созданы или могли быть созданы для суда над нацистскими преступниками [52].

Разработка норм и механизма уголовной ответственности за военные преступления в послевоенный период осуществлялась по следующим направлениям.

Во-первых, в разработанных под эгидой МККК источниках международного гуманитарного права (Женевских конвенциях о защите жертв войны 1949 г., и др.) уточнялся и дополнялся перечень серьезных нарушений законов и обычаев войны.

Во-вторых, в послевоенный период в целом комплексе международно-правовых норм, разработанных и принятых под эгидой ООН (Декларация о территориальном убежище от 14 декабря 1967 г., Конвенция о неприменимости сроков давности к военным преступлениям и преступлениям против человечности 1968 г., и др.) была проведена концепция военных преступлений как 
преступлений против мира и безопасности человечества.

Данный подход принципиально важен в плане осуществления принципа универсальной юрисдикции по делам о военных преступлениях, в соответствии с которым предание суду преступника происходит вне зависимости от места совершения им преступления и его гражданства.

В-третьих, в ООН, в развитие Нюрнбергских принципов, шла работа по разработке проекта Кодекса о преступлениях против мира и безопасности человечества. Так, в 1947 г. в резолюции 177 Генеральная Ассамблея ООН поручила Комиссии международного прав сформулировать принципы международного права, признанные в Уставе и Приговоре Нюрнбергского МВТ и составить на основе этого проект Кодекса о преступлениях против мира и безопасности человечества, и в этом же году Комиссия международного права приступила к данной работе, а в 1954 г. Комиссия представила с комментариями первый проект Кодекса преступлений против мира и безопасности человечеств [5].

Проект Кодекса 1954 г. (включал всего 4 статьи) не был принят ввиду отсутствия на тот момент международно-правовых документов, содержащих определение агрессии (Концептуальное определение агрессии было дано в резолюиии Генеральной Ассамблеи ООН 3314 от 14 декабря 1974 2. //Резолюичи, принятые Генеральной Ассамблеей на двадиать девятой сессии, 17 сент. - 18 дек. 1974 г. /ООН. Нью-Йорк, 1975. T. I. C. 181-182.

Примечательно, что определение агрессии согласно резолюиии ГА ООН 3314 было воспринято участниками обзорной конференции по Римскому статуту МУС, проходившей в 2010 г. в Кампалле (Уганда). В результате консенсуса участниками кон- ференциии была принята резолюиия RC/Res. 6, содержащая элементы состава данного преступления (приложения I,II) и были внесень поправки в Статут в виде новой cтатьи 8-bis (ранее n. 2 cm. 5 Cтатута предусматривал, что «...Суд осуществляет юрисдикцию в отношении преступления агрессии, как только будет принято в соответствии со статьями 121 и 123 положение, содержащее определение этого преступления и излагающее условия, в которых Суд осуществляет юрисдикцию касательно этого преступления...»; теперь этот пункт должен быть исключен из Статута). Юрисдикиия Суда возможна только после подтверждения поправок большинством в 2/3 голосов на Ассамблее государств-участников после 1 января 2017 г., причем Суд может осуществить юрисдикцию в отношении преступления агрессии, только если оно было совершено по истечении года с момента ратификации поправок 30 государствами-участниками. - Подробнее, См.: Трикоз Е.Н. Кампальская конферениия по международному уголовному правосудию // Международное уголовное право и международная юстищия. 2011. N 1. C. 20 - 24.), фактически работа над ним возобновилась только в 1982 году [63].

В-четвертых, в Женевские конвенции 1949 г. и Дополнительный протокол I 1977 г. был включен ряд положений, касающихся механизма формирования и реализации уголовной ответственности за военные преступления, при этом, основная роль в указанном механизме отводилась государствам-участникам [47, 42-43; 80, 83-92].

$\mathrm{B}$-пятых, в послевоенный период в $\mathrm{OOH}$ ведется разработка вопросов, связанных с созданием международного уголовного суда. Генеральная Ассамблея в 1948 г (Резолюичия 260 B (III) om 9 декабря 1948 г.). поставила перед Комиссией международного права вопрос о создании международного органа 
уголовного правосудия. Изучив данный вопрос, Комиссия международного права в 1950 г. пришла к заключению о том, что создание международного уголовного суда представляется и «желательным»и и «возможным» [30]. Подготовкой статута суда занималось несколько специальных комитетов (Док. ООН A/2136 (1951); Док. $O O H A / 2645$ (1954).). Однако в дальнейшем работа в данном направлении была приостановлена в связи с нерешенностью вопроса об определении агрессии, отсутствием кодекса соответствующих преступлений, а также политической обстановкой «холодной войны» [19, 3-4].

В-шестых, следует указать на развитие в послевоенный период национальных правовых систем в рассматриваемой сфере. По мере ратификации Женевских конвенций о защите жертв войны 1949 г. (а впоследствии - Дополнительных протоколов к ним, а также других международных договоров в сфере международного гуманитарного права) формируется практика национально-правовой имплементации установленных в этих конвенциях обязательств [35, 70-142; 12, 84-85].

С начала 1990-х годов и до настоящего времени процесс разработки рассматриваемых норм и механизма воспринимает послевоенный опыт и в целом развивается в русле обозначенных выше направлений.

Вместе с тем, наблюдаются новые тенденции.

Во-первых, активизируется работа по подготовке и принятию проекта Кодекса преступлений против мира и безопасности человечества. При этом положения вновь разрабатываемого Кодекса не только воспринимают фундаментальные идеи Нюрнбергского процесса, но и адаптируются к современным реалиям, содержат нововведения, обусловленные кодификацией и прогрессивным развитием международ- ного права, современной практикой его осуществления [68, 61-62]. Как отмечалось выше, работа по его подготовке в Комиссии международного права возобновилась в 1982 г., а в 1991 г. проект статей Кодекса был представлен и принят Комиссией в предварительном чтении, и затем через генерального секретаря ООН направлен правительствам стран для обсуждения [29]. С учетом поступивших замечаний от правительств и итогов обсуждения проекта Кодекса 1991 г. в шестом Комитете Генеральной Ассамблеи ООН, Комиссия в 1996 г. на 48-й сессии приняла окончательный проект Кодекса [28]. Предусмотренный в ст. 20 «Военные преступления» перечень включает семь категорий такого рода деяний (Это, преимущественно, серьезные нарушения Женевских конвенций 19492. и Дополнительного протокола I 1977 г. к ним; кроме того, пятая категория нарушений отражена в Гаагской конвенции о законах и обычаях сухопутной войны 1907 г. и приложенном к ней Положении о законах и обычаях сухопутной войны, отдельные из нарушений указанной категории посягают на культурные иенности, охраняемые Гаагской конвенцией о защите культурных иенностей в случае вооруженного конфликта 1954 г.; шестая категория военных преступлений, перечисленных в $\mathrm{cm}$. 20 (а отчасти, и четвертая) охватывает ряд серьезных нарушений международного гуманитарного права, применимого в условиях вооруженного конфликта, о которых говорится в cm. 4 Дополнительного протокола II 1977 г., а также в ст. 4 Устава Международного трибунала по Руанде. Ввиду того, что текст cm. 20 занимает более двух печатных странии (см. Доп. № 10 (A/51/10) C. 115-118), мы здесь не приводим его. Подробнее по вопросу квалификащии военных преступлений в проекте Кодекса преступлений против мира и безопасности че- 
ловечества, см.: Трикоз Е.Н. Преступления против мира и безопасности человечества: сравнительный и международно-правовой аспекты. С. 217-220; Комментарий к cm. 20 проекта Кодекса преступлений против мира и безопасности человечества //Доп. № 10 (A/51/10). С. 118-124.). Важно обратить внимание на то, что, во-первых, отнесение любого из указанных в ст. 20 военных преступлений к преступлениям против мира и безопасности человечества обусловлено их совершением систематически или в широких масштабах (Доп. № 10 (А/51/10). С. 115.), во-вторых, в проекте Кодекса криминализованы серьезные нарушения международного гуманитарного права, применимого в вооруженных конфликтах международного и немеждународного характера.

К сожалению, вопрос принятия проекта Кодекса преступлений против мира и безопасности человечества в форме международного договора не решен (Здесь заметим, что этот вопрос обсуждался в Комиссии международного права. Среди предложенных вариантов упоминались: международная конвенция, принятая в рамках Генеральной Ассамблеи ООН или на конференции полномочных представителей; инкорпорация положений Кодекса в текст Статута Международного уголовного суда; принятие Кодекса в форме декларации Генеральной Ассамблеи ООН. Профессор И.И. Лукашук предлагал сочетать обе формь - принять декларацию, а затем на ее основе разработать конвеничию. - См.: См.: Лукашук И.И. 48-я сессия Комиссии международного права // Московский журнал международного права. 1997. N 2. С. 182. Комиссия рекомендовала Генеральной Ассамблее ООН «выбрать наиболее подходящую форму, которая обеспечила бы как можно более возможное широкое признание проекта Кодекса». См.: Доп. № 10 (A/51/10). С. 28.).
Во-вторых, в рассматриваемый период реализуется идея создания постоянного международного уголовного суда. Итогом работы Комиссии международного права и широкого сотрудничества государств явились разработка Статута Международного уголовного суда (Его проект был принят Комиссией международного права в 1994 г. Обзор работы Комиссии международного права, а также предложений, поступавших от государств при разработке проекта Статута Международного уголовного суда дан в материалах ООН (Проект Устава Международного уголовного суда, принятый в 1994 г. на 46-й сессии Комиссии международного права //Официальные отчеты Генеральной Ассамблеи ООН, сорок девятая сессия, Доп. № 10 (A/49/10). С. 23-120; Комментарии правительств по докладу рабочей группы по проекту Устава Международного уголовного суда//Doc. A/CN. 4/458/Add. 7 (1994); и приводится в отечественной и зарубежной литературе. - См., например: Блищенко И.П., Фисенко И.В. Международный уголовный суд. - М., 1998; Верещетин В.С. Международный уголовный суд: новые перспективы? (К рассмотрению вопроса в Комиссии международного права ООН) //Московский журнал международного права. 1993. № 2 . C. 3-14; Он же: О работе Комиссии международного права ООН //Московский журнал международного права. 1994. № 1. С. 3-20; Грицаев С.А. Международная уголовная ответственность физических лиц: история и современность. - Белгород, 2005. 10-15; Колодкин Р.А., Панин И.А. Обсуждение проекта Устава Международного уголовного суда в специальном комитете Генеральной Ассамблеи ООН // Московский журнал международного права. 1996. N 4. С. $69-$ 80; Лобанов С.А. Международно-правовые аспекты уголовного судопроизводства по делам о военных преступлениях. - М., 
1999. C. 72-74; Crawford J. The Work of the International Law Commission // The Rome Statute of the International Criminal Court: a Commentary / Eds. by A. Cassese, P. Gaeta, J. Jones. Vol. I. P. 23 - 34), который был принят в Риме на дипломатической конференции полномочных представителей 17 июля 1998 г. (Док. ОOH A/CON F. 183/9. Подробнее о принятии и открытии к подписанию Римского статута, см,: Кирилл Г. Геворгян. Учреждение международного уголовного суда. Международное nраво. - International Law. 1998. № 3. C. 204-207.), и вступил в силу 1 июля 2002 г (После ратификаиии Статута 60 государствами. Подробнее, см.: Игнатенко Г.В. Международный уголовный суд как субъект международного права //Российский ежегодник международного права. 2003. Специиальный выпуск. СПб., 2003. С. 12-17. Россия пока не ратифицировала данный документ. В то же время наша страна, в отличие от ряда других (среди последних США и Китай), голосовала за принятие Римского cmamyma.).Непосредственно военным преступлениям посвящена ст. 8 Статута МУС, выделяющая четыре категории военных преступлений (их перечень насчитывает несколько десятков составов (Док $\mathrm{OOH}: \mathrm{A}$ / CONF. 183/9. P. 8-12)). Международный уголовный суд приступил к работе, им вынесен первый вердикт (Краткое описание дела «Прокурор против Томаса Лубанги Дьило» MУC. Дело № ICC-CPI-20120314-PR776. См.: офиичильный сайт Международного уголовного суда: URL:http://www.icc-cpi.int. См., также: Чернышев К. Первый приговор Международного уголовного суда: решение Судебной палаты I Международного уголовного суда от 14 марта 2012 года в соответствии со статьей 74 Римского статута по делу «Прокурор против Томаса Лубанги Дийло» // Международное правосудие. 2012. N 3. C. $24-31$ ).
В-третьих, параллельно с реализацией идеи создания постоянного Международного уголовного суда идет процесс создания такого рода органов ad hoc (международные уголовные трибуналы, соответственно, по бывшей Югославии и по Руанде, которые были созданы резолюциями Совета Безопасности $\mathrm{OOH}$, а также интернационализированные суды, создаваемые в соответствии с двусторонними договоренностями). Военные преступления входят в предметную юрисдикцию большинства указанных международных органов уголовного правосудия (Mы не останавливается здесь на критике работы Международного трибунала по бывшей Югославии, других аспектах организации и деятельности международных органов уголовного правосудия. Подробно об этом вопросе, см., например: Институты международного правосудия. - Iпод ред. В.Л. Толстых. - М.: Междунар. отношения, 2014 (раздел VII. Институты международного уголовного правосудия, авторы: Ледях И.А.; Егоров С.А., и др.).).

В-четвертых, поднимается на качественно новый уровень процесс национально-правовой имплементации международных обязательств, связанных не только с криминализацией рассматриваемых нарушений, принятием мер по их предупреждению и пресечению, но также с обеспечением взаимодействия государств с международными органами уголовной юстиции. Современные интеграционные и глобализационные процессы проявляют себя в широкой имплементации международно-правовых норм в уголовном праве государств [6, 222-229; 12 , 89-93; 27, 666-672].

Кроме того, отдельными странами помимо уголовных кодексов были приняты специальные законы, распространившие универсальную юрисдикцию на некоторые международные преступления. В частности, можно сослаться на бельгийский Закон от 16 июня 
1993 г. «О пресечении серьезных нарушений международного гуманитарного права» («Loi relative a la repression des violations graves du droit international humanitaire» [1, 918-925]), согласно ст. 7 которого судебные инстанции Бельгии вправе рассматривать дела о совершении нарушений, подпадающих под действие настоящего Закона, независимо от места их совершения [67, 69-74].

В связи с созданием постоянного органа международного уголовного правосудия и подключением государств к участию в его работе, расширяется и качественно преобразуется комплекс международно-правовых обязательств в исследуемой сфере. В литературе [27, 666-667] обращается внимание на то, что при имплементации Статута МУС государствам-участникам необходимо решить следующий комплекс задач: а) устранение противоречий между Статутом МУС и конституционными актами государства; б) приведение национального уголовного законодательства в соответствие с требованиями Статута МУС; в) создание правовой базы взаимодействия с Международным уголовным судом; как показывает практика, каждая из указанных задач может решаться различными путями, исходя из правовых традиций конкретной страны.

Проведенный историко-правовой анализ эволюции становления и развития норм об уголовной ответственности за военные преступления и институционально-правового механизма ее конкретизации и реализации позволяет выделить следующие периоды данного процесса: 1)зарождение запретов и ограничений, касающихся ведения войны и практики уголовной ответственности за их преступные нарушения (до XV в.); 2) становление внутригосударственной практики криминализации в военно-уголовном законодательстве отдельных нарушений законов и обычаев войны, формирование органов военной юстиции и специальных правил рас- следования и судебного рассмотрения дел о преступлениях военнослужащих, включая указанные нарушения (XVI в. - середина XIX в.); 3) попытки криминализации военных преступлений в международном праве и запуска основанного на международном праве институционального механизма уголовной ответственности за них, параллельное этим процессам развитие национального законодательства и правоприменительной практики в данной сфере (вторая половина XIX в. - начало Второй мировой войны); 4) криминализация военных преступлений в международном праве, создание органов международной уголовной юстиции, обладающих юрисдикцией в отношении них, установление международно-правовых обязательств государств по обеспечению неотвратимости наказания лиц, их совершивших, совершенствование норм национального уголовного, уголовно-процессуального и уголовно-исполнительного права в данной сфере (окончание Второй мировой войны - настоящее время).

В рамках четвертого периода, в свою очередь, выделяется современный этап (с начала 1990-х годов). Он характеризуется диверсификацией органов международной уголовной юстиции, созданием постоянного международного уголовного суда, развитием процесса национально-правовой имплементации международных обязательств, включающих, наряду с криминализацией рассматриваемых нарушений, принятием мер по их предупреждению и пресечению, также вопросы взаимодействия государств с органами международной уголовной юрисдикции. В целом правомерно утверждать, что в современных условиях постепенно складывается институционально-правовой механизм взаимодействия национальных и международных правоприменительных органов в сфере уголовной ответственности за военные преступления. 


\section{Библиография:}

1. Belgium: Act Concerning the Punishment of Grave Breaches of International Humanitarian Law // International Legal Materials. 1999. Vol. XXXVIII. No. 4.

2. Crawford J. The Work of the International Law Commission // The Rome Statute of the International Criminal Court: a Commentary / Eds. by A. Cassese, P. Gaeta, J. Jones. Vol. I.

3. History of the United Nations War Crimes Commission and the Development of the Laws of War. 1948.

4. Tusa A. and Tusa J. The Nuremberg Trial. N.Y., 1963; Bantekas I., Nash S. International Criminal Law. L.; N.Y., 2007.

5. Yearbook of the International Law Commission, 1954. Vol. II. Draft Code of Offences against the Peace and Security of Mankind, 1954 // http://www.un.org/law/ilc/convents.

6. Адельханян Р.А. Военные преступления в современном праве.

7. Алексеев С.С. Теория права. М., 1993.

8. Арцибасов И.Н., Егоров С.А. Вооруженный конфликт: право, политика, дипломатия. М., 1989.

9. Бабенко Р.В. История становления и пути развития военных судов России [Электронный ресурс] // История государства и права. 2007. №

10. Доступ из справ. - правовой системы «Консультант Плюс». 10.Батырь В.А. Нюрнбергский приговор пересмотру не подлежит //Вестник Академии Генеральной прокуратуры Российской Федерации. 2011. № 2.

11. Беккер К.Ф. История Древнего мира. Восток. Греция. М., 2001.

12. Белый И.Ю. Международное уголовное судопроизводство по делам о военных преступлениях (проблемы становления и перспективы развития): Дис....доктора юрид. наук. - М., 2009.

13. Белый И.Ю. Нюрнбергский процесс и формирование принципов международного уголовного судопроизводства // Вестник Академии Генеральной прокуратуры Российской Федерации. 2011. № 2.

14. Блищенко И.П., Фисенко И.В. Международный уголовный суд. - М., 1998;

15. Бобровский П.О. Военное право в России при Петре Великом. Артикул воинский. СПб., 1882. Вып. 1. Ч. 2.

16. Богуш Г.И. Нюрнбергский процесс и современность (некоторые размышления к 60-летию Международного военного трибунала над главными нацистскими военными преступниками // Российский ежегодник уголовного права. - 2006. - № 1. - СПб., 2007;

17. Буткевич О.В. Формирование элементов системы международного правосудия в Средние века // Российский юридический журнал. 2012. N 4.

18. Валеев Р.М. Историческая роль России в проведении Гаагских конференций мира // История государства и права. 2009. N 12. С. 2-5; N 13.

19. Верещетин В.С. Международный уголовный суд: новые перспективы (К рассмотрению вопроса в Комиссии международного права ООН) //Московский журнал международного права. 1993. № 2 .

20. Винокуров А.Ю. Международно-правовые, теоретические и организационные основы уголовного преследования за совершение военных преступлений в отношении гражданского населения. - М., 2011.

21. Военное право. Курс лекций /Под ред. Н.А. Петухова. М.: Прогресс, 2002.

22. Волеводз А.Г. Правовое регулирование новых направлений международного сотрудничества в сфере уголовного процесса. - М.: Юрлитинформ, 2002.

23. Волеводз А.Г., Волеводз В.А. К 10-летию учреждения Международного уголовного суда. Исторические и международно-правовые предпосылки формирования современной системы международной уголовной юстиции [Электронный ресурс] //Международное уголовное право и международная юстиция. 2008. № 2. Доступ из справ. - правовой системы «Консультант Плюс».

24. Григорьев О.В. Рассмотрение дел в судах по Военно-судебному уставу 1867 г. // История государства и права. 2009. N 23

25. Грицаев С.А. Международная уголовная ответственность физических лиц: история и современность. - Белгород, 2005. 10-15; 
26. Действующее международное право. Т. 2.- М.: Московский независимый институт международного права, 1997.

27. Додонов В.Н. Модели имплементации Римского статута Международного уголовного суда в национальных законодательствах зарубежных стран //Международное уголовное правосудие. Современные проблемы /Под ред. Г.И. Богуша, Е.Н. Трикоз. - М., 2009.

28. Доклад Комиссии международного права о работе ее сорок восьмой сессии (6 мая - 26 июля 1996 года) //Генеральная Ассамблея. Официальные отчеты. Пятьдесят первая сессия. Доп. № 10 (А/51/10). Организация Объединенных наций. Нью-Йорк, 1996.

29. Доклад Комиссии международного права о работе ее сорок третьей сессии (29 апреля - 19 июля 1991 года) //Генеральная Ассамблея. Официальные отчеты. Сорок шестая сессия. Доп. № 10 (A/46/10). Организация Объединенных наций. Нью-Йорк, 1991.

30. Ежегодник Комиссии международного права. 1950. Т. II. Доклад Генеральной Ассамблее. - П. 128-145.

31. Елисеев Р.А. Международное уголовное право: особенности правореализации. Автореф. дис...к.ю.н.

32. Ермолович Я.Н. Влияние Нюрнбергского процесса на развитие российского военно-уголовного законодательства // Вестник Академии Генеральной прокуратуры Российской Федерации. 2011. № 2.

33. Загорский Г.И. Военно-судебная реформа 1867 г. // История государства и права. 2013. N 3.

34. Законодательство Петра I. - М., 1997.

35. Имплементация международного гуманитарного права. Статьи, документы. - М.: МККК, 1998.

36. Институты международного правосудия. -/под ред. В.Л. Толстых. - М.: Междунар. отношения, 2014 (раздел VII. Институты международного уголовного правосудия, авторы: Ледях И.А.; Егоров С.А., и др.).

37. Кальсховен Ф. Ограничения методов и средств ведения войны. - М.: МККК, 1994.

38. Карев Д.С. Нюрнбергский процесс. - М., 1976;

39. Кирилл Г. Геворгян. Учреждение международного уголовного суда. Международное право. International Law. 1998. № 3.

40. Коваль А.В. Значение Нюрнбергского трибунала для становления принципов международной уголовной ответственности // Вестник Академии Генеральной прокуратуры Российской Федерации. 2011. № 2.

41. Колодкин Р.А., Панин И.А. Обсуждение проекта Устава Международного уголовного суда в специальном комитете Генеральной Ассамблеи ООН // Московский журнал международного права. 1996. N 4.

42. Концептуальное определение агрессии было дано в резолюции Генеральной Ассамблеи ООН 3314 от 14 декабря 1974 г. //Резолюции, принятые Генеральной Ассамблеей на двадцать девятой сессии, 17 сент. - 18 дек. 1974 г. /ООН. Нью-Йорк, 1975. Т. І.

43. Коркунов И.М. Международное право. Лекции, читанные в Военно-юридической академии. СПб., 1886.

44. Коровин Е.А. Международные договоры и акты нового времени. Сборник. - М. - Л.: Госиздат, 1924.

45. Корякин В.М. Уроки Нюрнберга в зеркале военно-правовой науки // Вестник Академии Генеральной прокуратуры Российской Федерации. 2011. № 2.

46. Котляров И.И. Выполнение Россией договорных обязательств по международному гуманитарному праву: история и современность //Московский журнал международного права. 2003. № 1.

47. Кристоф Свинарски. Основные понятия и институты международного гуманитарного права как система защиты человека. - М.: Международный Комитет Красного Креста, 1997.

48. Крылов С.Б. Ученый, юрист, дипломат //Московский журнал международного права. 1996. № 1.

49. Лобанов С.А. Международно-правовые аспекты уголовного судопроизводства по делам о военных преступлениях. - М., 1999.

50. Лукашук И.И. 48-я сессия Комиссии международного права // Московский журнал международного права. 1997. N 2.

51. Маликов С.В. Расследование преступлений в боевой обстановке (правовое обеспечение, организация, методика): Дис...канд. юрид. наук. - М., 1998.

52. Международное гуманитарное право /Под ред. И.И. Котлярова.

53. Международное право: Учебник /отв. ред. В.И. Кузнецов. - М.: Юристъ, 2001.

54. Николаев А.Н. Токио: Суд народов. - М., 1990.

55. Нюрнбергский процесс: право против войны и фашизма. М., 1995; 
56. Оноколов Ю.П. Развитие военно-уголовного законодательства в советский период // Военноюридический журнал. 2010. N 7.

57. Петухов Н.А. Социально-правовые проблемы становления и развития системы военных судов в России: монография /Под ред. А.А. Толкаченко. - М., 2003.

58. Пикте Ж. Развитие и принципы международного гуманитарного права. М.: МККК, 1994.

59. Положения о введении в действие Военно-судебного устава, Наказа военно-судебным местам. - М.: Изд. А. Павлова, 1867. О значении данного законодательного акта

60. Полянский Н.Н. Международное правосудие и преступники войны. М., 1945.

61. Правовые основы применения вооруженных сил в XXI веке //Материалы Международной конференции, посвященной столетию первой Гаагской конференции мира 1899 года (18-19 мая 1999 года). - М.: МККК, 1999.

62. Пустогаров В.В. Ф.Ф. Мартенс-творец международного права // Государство и право. 1995. N 11.

63. Резолюция Генеральной Ассамблеи ООН 36/106 от 10 декабря 1981 г.

64. Резолюция Генеральной Ассамблеи ООН 95 (1) от 11 декабря 1946 г. //Нюрнбергский процесс. Сборник материалов в 8 т. Т.7. - М., 1961.

65. Сафиуллина И.П. Нюрнбергские принципы и их влияние на формирование международных уголовных судов в современных условиях: дис. ... канд. юрид. наук. Казань, 2003;

66. Сидорин В.В., Шулепов Н.А. Теоретические основы совершенствования военно-уголовного законодательства с использованием опыта зарубежных стран. - М.: Академия ФПС России, 2000.

67. Скуратова А.Ю. Международные преступления: современные проблемы квалификации. - М.: Норма: ИНФРА-М, 2012.

68. Скуратова А.Ю. Международные преступления: современные проблемы квалификации. М.: Норма, 2012.

69. Слободанюк И.А. Влияние Нюрнбергского процесса на развитие концепции международной военной безопасности // Вестник Академии Генеральной прокуратуры Российской Федерации. 2011. № 2.

70. Сухарев А.Я, Хлестов О.Н., Прокофьев Н.В. Уроки Нюрнберга (к 60-летию Нюрнбергского процесса) //Международное право - International Law. 2006. № 2 (26).

71. Сухарев А.Я. Нюрнбергский процесс и проблемы международной законности //Журнал российского права. 2007. № 1;

72. Толкаченко А.А. Становление и развитие системы исполнения уголовных наказаний в России (военно-пенитенциарные). М., 1997.

73. Трикоз Е.Н. 60-летняя годовщина завершения Нюрнбергского судебного процесса //Журнал российского права. 2007. № 1;

74. Трикоз Е.Н. Кампальская конференция по международному уголовному правосудию // Международное уголовное право и международная юстиция. 2011. N 1.

75. Трикоз Е.Н. Преступления против мира и безопасности человечества: сравнительный и международно-правовой аспекты. М., 2007.

76. Устав военно-уголовный, 1839 г. // Свод военных постановлений. 1859. Ч. V.

77. Хенкертс Ж. - М., Досвальд-Бек Л. Обычное международное гуманитарное право. Нормы. МККК, 2006. T. I.

78. Чернышев К. Первый приговор Международного уголовного суда: решение Судебной палаты I Международного уголовного суда от 14 марта 2012 года в соответствии со статьей 74 Римского статута по делу «Прокурор против Томаса Лубанги Дийло»// Международное правосудие. 2012. N 3.

79. Шайкин В.И. Законы и обычаи войны в русской военной истории [Электронный ресурс] // Военноюридический журнал. 2010. N 2. С. 28-32. Доступ из справ. - правовой системы «Консультант Плюс».

80. Штурма П. Универсальная юрисдикция и наказание за серьезные нарушения Женевских конвенций 1949 г. // Известия вузов. Правоведение. 2010. N 4.

81. Юшин В.Ю. Историко-юридическая характеристика военно-уголовного законодательства России [Электронный ресурс] //Военно-юридический журнал. 2008. № 4. Доступ из справ. - правовой системы «Консультант Плюс». 


\section{References (transliterated):}

1. Belgium: Act Concerning the Punishment of Grave Breaches of International Humanitarian Law // International Legal Materials. 1999. Vol. XXXVIII. No. 4.

2. Crawford J. The Work of the International Law Commission // The Rome Statute of the International Criminal Court: a Commentary / Eds. by A. Cassese, P. Gaeta, J. Jones. Vol. I.

3. Tusa A. and Tusa J. The Nuremberg Trial. N.Y., 1963; Bantekas I., Nash S. International Criminal Law. L.; N.Y., 2007.

4. Adel'khanyan R.A. Voennye prestupleniya v sovremennom prave.

5. Alekseev S.S. Teoriya prava. M., 1993.

6. Artsibasov I.N., Egorov S.A. Vooruzhennyi konflikt: pravo, politika, diplomatiya. M., 1989.

7. Babenko R.V. Istoriya stanovleniya i puti razvitiya voennykh sudov Rossii [Elektronnyi resurs] //Istoriya gosudarstva i prava. 2007. №

8. Bekker K.F. Istoriya Drevnego mira. Vostok. Gretsiya. M., 2001.

9. Belyi I.Yu. Mezhdunarodnoe ugolovnoe sudoproizvodstvo po delam o voennykh prestupleniyakh (problemy stanovleniya i perspektivy razvitiya): Dis....doktora yurid. nauk. - M., 2009.

10. Belyi I.Yu. Nyurnbergskii protsess i formirovanie printsipov mezhdunarodnogo ugolovnogo sudoproizvodstva // Vestnik Akademii General'noi prokuratury Rossiiskoi Federatsii. 2011. № 2.

11. Blishchenko I.P., Fisenko I.V. Mezhdunarodnyi ugolovnyi sud. - M., 1998;

12. Bobrovskii P.O. Voennoe pravo v Rossii pri Petre Velikom. Artikul voinskii. SPb., 1882. Vyp. 1. Ch. 2.

13. Bogush G.I. Nyurnbergskii protsess i sovremennost' (nekotorye razmyshleniya k 60-letiyu Mezhdunarodnogo voennogo tribunala nad glavnymi natsistskimi voennymi prestupnikami //Rossiiskii ezhegodnik ugolovnogo prava. - 2006. - № 1. - SPb., 2007;

14. Butkevich O.V. Formirovanie elementov sistemy mezhdunarodnogo pravosudiya v Srednie veka // Rossiiskii yuridicheskii zhurnal. 2012. N 4.

15. Valeev R.M. Istoricheskaya rol' Rossii v provedenii Gaagskikh konferentsii mira // Istoriya gosudarstva i prava. 2009. N 12. S. 2-5; N 13.

16. Vereshchetin V.S. Mezhdunarodnyi ugolovnyi sud: novye perspektivy (K rassmotreniyu voprosa v Komissii mezhdunarodnogo prava OON) //Moskovskii zhurnal mezhdunarodnogo prava. 1993. № 2.

17. Vinokurov A.Yu. Mezhdunarodno-pravovye, teoreticheskie i organizatsionnye osnovy ugolovnogo presledovaniya za sovershenie voennykh prestuplenii v otnoshenii grazhdanskogo naseleniya. - M., 2011.

18. Volevodz A.G. Pravovoe regulirovanie novykh napravlenii mezhdunarodnogo sotrudnichestva v sfere ugolovnogo protsessa. - M.: Yurlitinform, 2002.

19. Volevodz A.G., Volevodz V.A. K 10-letiyu uchrezhdeniya Mezhdunarodnogo ugolovnogo suda. Istoricheskie i mezhdunarodno-pravovye predposylki formirovaniya sovremennoi sistemy mezhdunarodnoi ugolovnoi yustitsii [Elektronnyi resurs] //Mezhdunarodnoe ugolovnoe pravo i mezhdunarodnaya yustitsiya. 2008. № 2. Dostup iz sprav. - pravovoi sistemy «Konsul'tant Plyus».

20. Grigor'ev O.V. Rassmotrenie del v sudakh po Voenno-sudebnomu ustavu 1867 g. // Istoriya gosudarstva i prava. 2009. N 23

21. Gritsaev S.A. Mezhdunarodnaya ugolovnaya otvetstvennost' fizicheskikh lits: istoriya i sovremennost'. Belgorod, 2005. 10-15;

22. Eliseev R.A. Mezhdunarodnoe ugolovnoe pravo: osobennosti pravorealizatsii. Avtoref. dis...k.yu.n.

23. Ermolovich Ya.N. Vliyanie Nyurnbergskogo protsessa na razvitie rossiiskogo voenno-ugolovnogo zakonodatel’stva // Vestnik Akademii General'noi prokuratury Rossiiskoi Federatsii. 2011. № 2.

24. Zagorskii G.I. Voenno-sudebnaya reforma 1867 g. // Istoriya gosudarstva i prava. 2013. N 3.

25. Kal'skhoven F. Ogranicheniya metodov i sredstv vedeniya voiny. - M.: MKKK, 1994.

26. Karev D.S. Nyurnbergskii protsess. - M., 1976;

27. Kirill G. Gevorgyan. Uchrezhdenie mezhdunarodnogo ugolovnogo suda. Mezhdunarodnoe pravo. International Law. 1998. № 3.

28. Koval' A.V. Znachenie Nyurnbergskogo tribunala dlya stanovleniya printsipov mezhdunarodnoi ugolovnoi otvetstvennosti // Vestnik Akademii General'noi prokuratury Rossiiskoi Federatsii. 2011. № 2. 
29. Kolodkin R.A., Panin I.A. Obsuzhdenie proekta Ustava Mezhdunarodnogo ugolovnogo suda v spetsial'nom komitete General'noi Assamblei OON // Moskovskii zhurnal mezhdunarodnogo prava. 1996. N 4.

30. Korkunov I.M. Mezhdunarodnoe pravo. Lektsii, chitannye v Voenno-yuridicheskoi akademii. SPb., 1886.

31. Korovin E.A. Mezhdunarodnye dogovory i akty novogo vremeni. Sbornik. - M. - L.: Gosizdat, 1924.

32. Koryakin V.M. Uroki Nyurnberga v zerkale voenno-pravovoi nauki // Vestnik Akademii General'noi prokuratury Rossiiskoi Federatsii. 2011. № 2.

33. Kotlyarov I.I. Vypolnenie Rossiei dogovornykh obyazatel'stv po mezhdunarodnomu gumanitarnomu pravu: istoriya i sovremennost' //Moskovskii zhurnal mezhdunarodnogo prava. 2003. № 1.

34. Kristof Svinarski. Osnovnye ponyatiya i instituty mezhdunarodnogo gumanitarnogo prava kak sistema zashchity cheloveka. - M.: Mezhdunarodnyi Komitet Krasnogo Kresta, 1997.

35. Krylov S.B. Uchenyi, yurist, diplomat //Moskovskii zhurnal mezhdunarodnogo prava. 1996. № 1.

36. Lobanov S.A. Mezhdunarodno-pravovye aspekty ugolovnogo sudoproizvodstva po delam o voennykh prestupleniyakh. - M., 1999.

37. Lukashuk I.I. 48-ya sessiya Komissii mezhdunarodnogo prava // Moskovskii zhurnal mezhdunarodnogo prava. 1997. N 2.

38. Malikov S.V. Rassledovanie prestuplenii v boevoi obstanovke (pravovoe obespechenie, organizatsiya, metodika): Dis...kand. yurid. nauk. - M., 1998.

39. Nikolaev A.N. Tokio: Sud narodov. - M., 1990.

40. Onokolov Yu.P. Razvitie voenno-ugolovnogo zakonodatel'stva v sovetskii period // Voenno-yuridicheskii zhurnal. 2010. N 7.

41. Petukhov N.A. Sotsial'no-pravovye problemy stanovleniya i razvitiya sistemy voennykh sudov v Rossii: monografiya /Pod red. A.A. Tolkachenko. - M., 2003.

42. Pikte Zh. Razvitie i printsipy mezhdunarodnogo gumanitarnogo prava. M.: MKKK, 1994.

43. Polyanskii N.N. Mezhdunarodnoe pravosudie i prestupniki voiny. M., 1945.

44. Pustogarov V.V. F.F. Martens-tvorets mezhdunarodnogo prava // Gosudarstvo i pravo. 1995. N 11.

45. Safiullina I.P. Nyurnbergskie printsipy i ikh vliyanie na formirovanie mezhdunarodnykh ugolovnykh sudov v sovremennykh usloviyakh: dis. ... kand. yurid. nauk. Kazan', 2003;

46. Sidorin V.V., Shulepov N.A. Teoreticheskie osnovy sovershenstvovaniya voenno-ugolovnogo zakonodatel'stva $\mathrm{s}$ ispol'zovaniem opyta zarubezhnykh stran. - M.: Akademiya FPS Rossii, 2000.

47. Skuratova A.Yu. Mezhdunarodnye prestupleniya: sovremennye problemy kvalifikatsii. - M.: Norma: INFRA-M, 2012.

48. Skuratova A.Yu. Mezhdunarodnye prestupleniya: sovremennye problemy kvalifikatsii. M.: Norma, 2012.

49. Slobodanyuk I.A. Vliyanie Nyurnbergskogo protsessa na razvitie kontseptsii mezhdunarodnoi voennoi bezopasnosti // Vestnik Akademii General'noi prokuratury Rossiiskoi Federatsii. 2011. № 2.

50. Sukharev A.Ya, Khlestov O.N., Prokof'ev N.V. Uroki Nyurnberga (k 60-letiyu Nyurnbergskogo protsessa) // Mezhdunarodnoe pravo - International Law. 2006. № 2 (26).

51. Sukharev A.Ya. Nyurnbergskii protsess i problemy mezhdunarodnoi zakonnosti //Zhurnal rossiiskogo prava. 2007. № 1;

52. Tolkachenko A.A. Stanovlenie i razvitie sistemy ispolneniya ugolovnykh nakazanii v Rossii (voenno-penitentsiarnye). M., 1997.

53. Trikoz E.N. 60-letnyaya godovshchina zaversheniya Nyurnbergskogo sudebnogo protsessa //Zhurnal rossiiskogo prava. 2007. № 1;

54. Trikoz E.N. Kampal'skaya konferentsiya po mezhdunarodnomu ugolovnomu pravosudiyu // Mezhdunarodnoe ugolovnoe pravo i mezhdunarodnaya yustitsiya. 2011. N 1.

55. Trikoz E.N. Prestupleniya protiv mira i bezopasnosti chelovechestva: sravnitel'nyi i mezhdunarodno-pravovoi aspekty. M., 2007.

56. Khenkerts Zh. - M., Dosval'd-Bek L. Obychnoe mezhdunarodnoe gumanitarnoe pravo. Normy. MKKK, 2006. T. I.

57. Chernyshev K. Pervyi prigovor Mezhdunarodnogo ugolovnogo suda: reshenie Sudebnoi palaty I Mezhdunarodnogo ugolovnogo suda ot 14 marta 2012 goda v sootvetstvii so stat'ei 74 Rimskogo statuta po delu "Prokuror protiv Tomasa Lubangi Diilo" // Mezhdunarodnoe pravosudie. 2012. N 3. 
DOI: $10.7256 / 2226-6305.2016 .1 .16889$

При цитировании этой статьи сноска на doi обязательна

История международного права и международных организаций/ History of international law and international organizations

58. Shaikin V.I. Zakony i obychai voiny v russkoi voennoi istorii [Elektronnyi resurs] // Voenno-yuridicheskii zhurnal. 2010. N 2. S. 28-32. Dostup iz sprav. - pravovoi sistemy «Konsul'tant Plyus».

59. Shturma P. Universal'naya yurisdiktsiya i nakazanie za ser'eznye narusheniya Zhenevskikh konventsii 1949 g. // Izvestiya vuzov. Pravovedenie. 2010. N 4.

60. Yushin V.Yu. Istoriko-yuridicheskaya kharakteristika voenno-ugolovnogo zakonodatel'stva Rossii [Elektronnyi resurs] //Voenno-yuridicheskii zhurnal. 2008. № 4. Dostup iz sprav. - pravovoi sistemy «Konsul’tant Plyus». 